\title{
ENVIRONMENTAL UTILITY OF CELTIS AND STYPHNOLOBIUM SPECIES IN URBAN ENVIRONMENTS IN TERMS OF TREE AGE
}

\author{
Tímea, Kiss \\ John von Neumann University, \\ Faculty of Horticulture and Rural Development, Department of Horticulture \\ https://doi.org/10.47833/2021.1.AGR.005
}

\section{Keywords:}

tree age

environmental utility

Celtis occidentalis

Styphnolobium japonicum

\section{Article history:}

Received 10 Marc 2021

Revised 18 Marc 2021

Accepted 2 Apr 2021

\begin{abstract}
The environmental benefits of trees are obvious, as they have a positive effect on the microclimate of a given area, be it a park, a public area covered with trees or a road lined with trees. Nor can their important role in filtering out contaminants and dust be neglected. With our study, we also want to prove this importance through two genera.
\end{abstract}

\section{Introduction}

Our survey was carried out in the center of Kecskemét, where Celtis occidentalis (70 individuals) and Styphnolobium japonicum (26 individuals) are present in high proportions among woody plants. Many individuals already attract attention with their habitus. In our study, we estimated the amount of foliage of these trees and thus determined the amount of $\mathrm{O}_{2}$ they produced and the amount of $\mathrm{CO}_{2}$ sequestered. We also investigated their importance in scavenging airborne dust and increasing air humidity. In our study, we also show the monetary value of these plants.

\section{Material and method}

Measurements:

In the first step, we determined the species and, if necessary, the variety of the woody plant. During the survey, each plant was given a unique identifier: an abbreviation of a scientific name and a serial number obtained during the survey. (Ex.: CO04 - Celtis occidentalis 4th in order). A total of 243 plants and 45 taxa were recorded, of which 96 individuals of two species were examined in detail in the present study. Species were determined based on Tóth [10]. The work of Schmidt and Tóth [7] was used as a basis for determining the shape of the canopy [9].

In our work we determined the height of the trees (using the method of equal triangles), within which we also measured the height of the trunks. To determine the volume, it was also necessary to calculate the area of the canopy projection. To calculate this, the radius of the crown was measured in four directions and then averaged to calculate this area (Figure 1) [10]. 


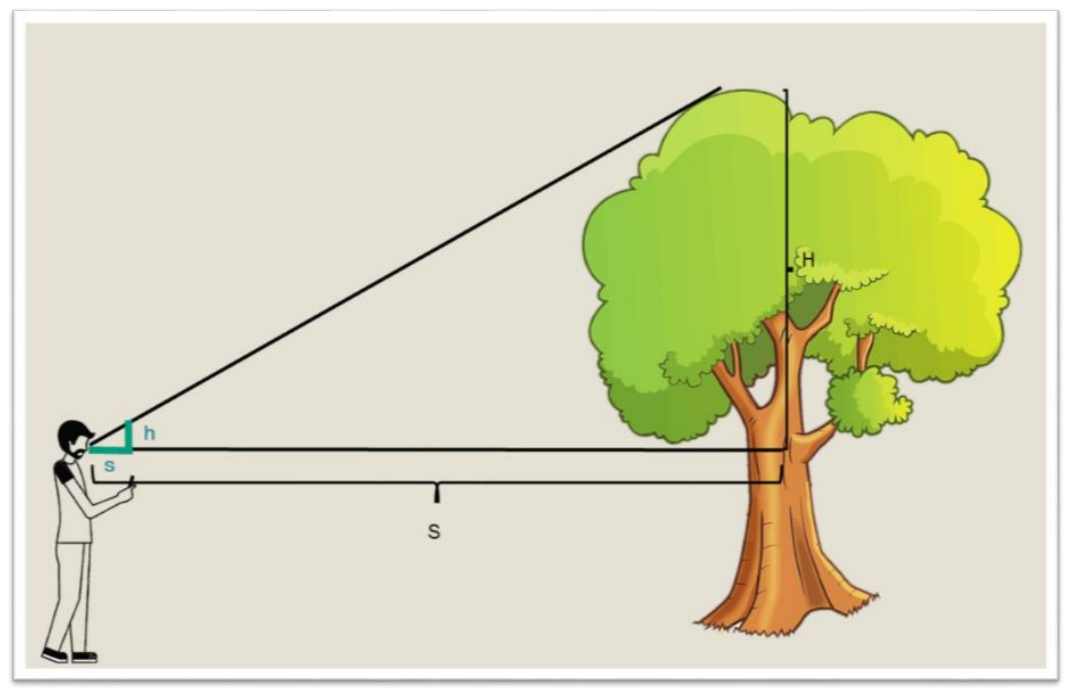

Figure 1. Schematic drawing of tree height calculation

For the measurement we used a measuring rod, measuring tape and, where possible, the Möller MR70664 laser rangefinder. From the available data, we calculated the canopy height of the trees. We also calculated canopy volume, which was calculated by different multipliers per crown form based on the work of Coder [4].

Knowing the value of the crown volume, we were able to calculate the value of environmental utility. This data shows the biologically active surface and value of the examined woody plants included in the survey. The examined data are crown volume $\left(\mathrm{m}^{3}\right)$, amount of produced $\mathrm{O}_{2}$ and bound $\mathrm{CO}_{2}$ during the growing season $(\mathrm{kg})$, dust binding $(\mathrm{kg})$ and evaporation (l). These data are a good illustration of the environmental utility of woody plants, which is determined by the surface area and volume of the crown.

To determine the value, it is necessary to determine the age of the trees. This required knowledge of the trunk size of the trees, which was measured at a height of one meter from the ground surface of the trees. To determine the age of the trees, we calculated the trunk diameters from these data so that we could assign an approximate age to the two studied taxa using the table of Radó [5]. To determine the tree value, we used the plant evaluation method developed by lldikó Jószainé Párkányi [3]. The daily nursery price was collected from the 2019-20 catalog of Juniperus Garden and the price list of Tahi Faiskola Kft.

Based on these, the tree value is determined:

Tree value $=$ daily nursery price $\times$ age multiplier $\times$ location coefficient $\times$ health status multiplier.

\section{Results}

\subsection{The age of the trees}

In our survey, we measured 70 Celtis occidentalis and 26 Styphnolobium japonicum. In both species, it can be said that the number of individuals is small, but most of them belong to older age groups. Figure 2 shows a higher proportion of Celtis occidentalis (29\%) in the youngest age group, which is explained by the fact that several young specimens were planted to the existing tree rows as a result of the reconstruction works in the main square. However, the highest proportion of both species can be classified into the 51-60 age group. Among the trees examined, several specimens are over 60 years old. The average age of the trees of the two species is as follows: Celtis occidentalis 53 years, Styphnolobium japonicum 52 years. 


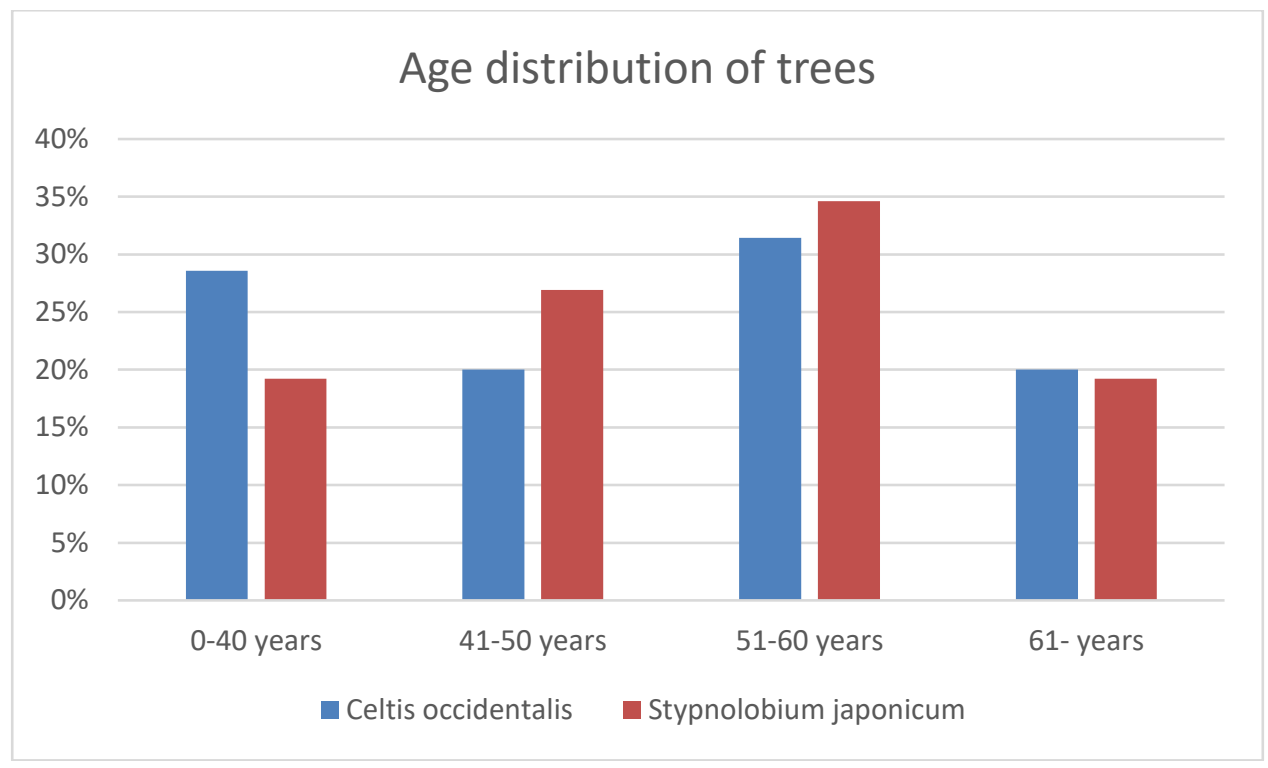

Figure 2: Age distribution of trees

\section{$3.2 \mathrm{O}_{2}$ production and $\mathrm{CO}_{2}$ sequestration in trees}

The assimilating surface of the species included in the study for Celtis occidentalis is 10148 $\mathrm{m}^{3}$; and $3942 \mathrm{~m}^{3}$ for Styphnolobium japonicum (the latter data is $38.85 \%$ of the volume of common hackberry). Together, the two taxa have a capacity of $14090 \mathrm{~m}^{3}$, which is more than 5.5 ha (56360 $\mathrm{m}^{2}$ ) in horizontal projection. From this, the value of the average foliage per specimen can be calculated, which is $144.97 \mathrm{~m}^{3}$ for common hackberry and $151.62 \mathrm{~m}^{3}$ for Japanese pagoda tree.

$\mathrm{O}_{2}$ emissions from individuals belonging to the two taxa range on average from 85 to $90 \mathrm{~kg}$ (Figure 3). It can be said that these trees make a significant contribution to people's oxygen needs. If a person inhales $3 \mathrm{~kg}$ of oxygen a day, these trees each supply 24-30 people with the oxygen necessary for life.

\section{$\mathrm{O}_{2}$ production and $\mathrm{CO}_{2}$ sequestration in trees}
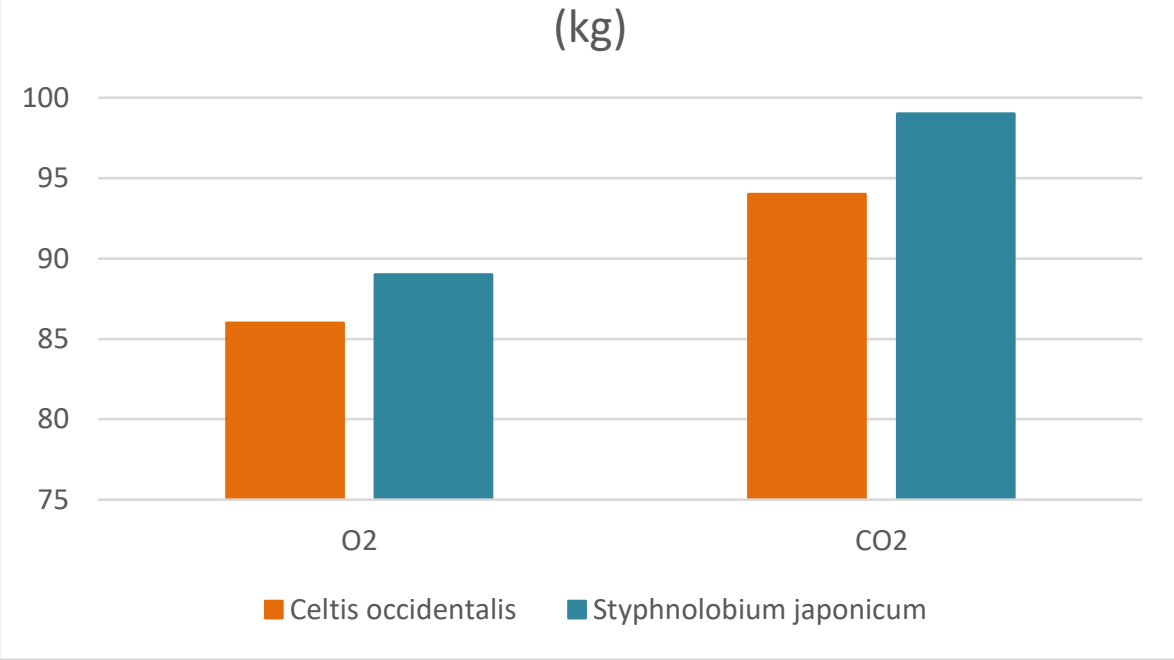

Figure 3: $\mathrm{O}_{2}$ production and $\mathrm{CO}_{2}$ sequestration in trees

Individuals of both species sequester significant amounts $(90-100 \mathrm{~kg})$ of $\mathrm{CO}_{2}$ during their growing season. A car emits approximately $20-27 \mathrm{~kg}$ of $\mathrm{CO}_{2}$ per $100 \mathrm{~km}$ [8]. The studied plants neutralize the emissions of an average of 4-5 cars. 


\subsection{Changes in the crown shape of trees with age}

Although both species studied are presented in the literature as spherical crown shapes without central leader [10], [[2] mentions that width of Styphnolobium japonicum, planted in the Royal Botanic Gardens in England in 1753, is still growing.

In this connection, we also examined the crown rays (LS) of the 100 and 200-leaf-cubic-meter specimens, respectively. From the average values it can be read that in the case of individuals larger than $100 \mathrm{~m}^{3}$ the difference between the two species is barely $30 \mathrm{~cm}$, while this value is twice as high for specimens larger than $200 \mathrm{~m}^{3}$. (Presumably, this difference would be even more pronounced if there were greater plant spacing between individuals in the area.) So common hackberry trees hardly grow horizontally in the second half of their lives, but Japanese pagoda tree crowns flatten more and more over time, increasing plant foliage and environmental usefulness.

\subsection{Pollution fixation of trees}

The most significant pollutants are sulfur dioxide, oxidized nitrogen compounds $\left(\mathrm{NO}_{2}, \mathrm{NO}\right)$, carbon monoxide and flour. In addition, solid atmospheric components (dust, particles) should be mentioned, the most dangerous of which are fractions with a particle size of less than 10 and $2.5 \mathrm{~m}$, respectively [1]. In the case of these particles, however, the binding capacity of the foliage can be taken into account not only once, but the biological filtering effect reappears after each precipitation. Celtis occidentalis individuals in the main square bind an average of $652 \mathrm{~kg}$ of contaminants, while Styphnolobium japonicum bind $682 \mathrm{~kg}$ (Figure 4).

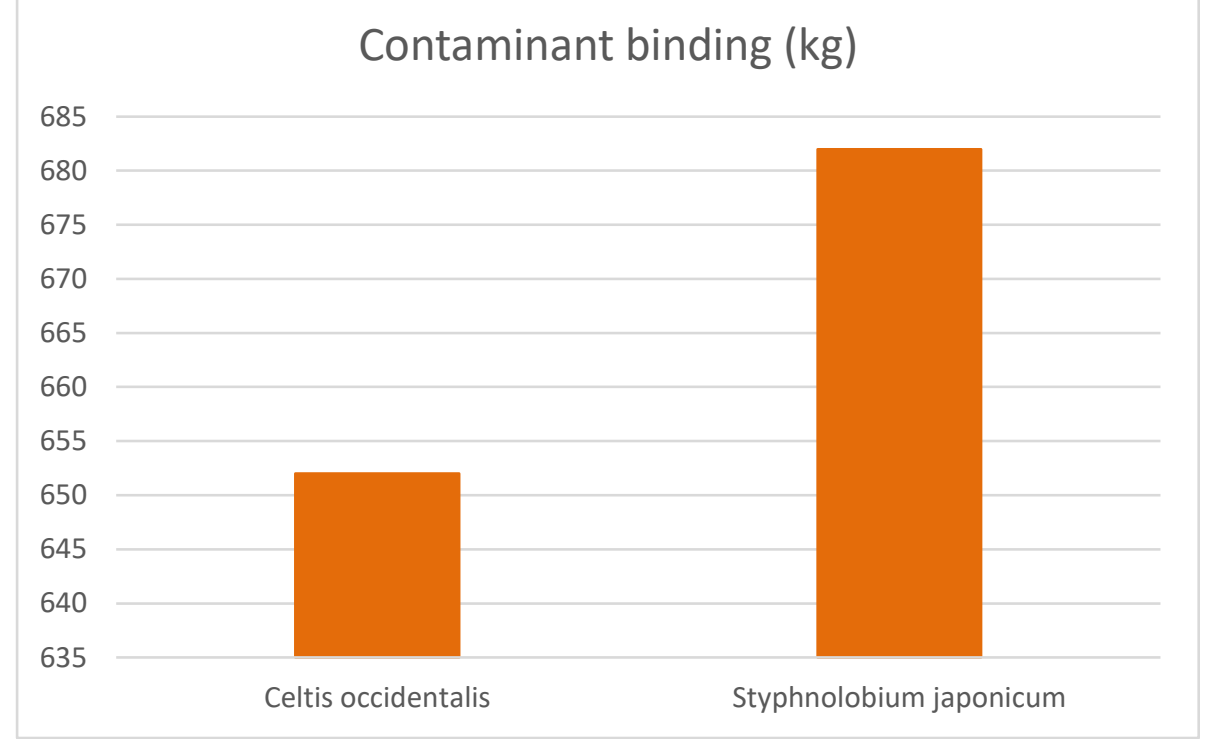

Figure 4: Contaminant binding

\subsection{Evaporation of trees}

The rate of evaporation in a tree-covered area can be up to 300-400 liters per square meter per year. This results in a significant increase in humidity (on average 5-6\%), and the energyabsorbing capacity of such a large body of water is considerable (732-919 thousand kJ), which can reduce the air temperature by $10-13^{\circ} \mathrm{C}$ [[6]. Our measurements show that a Styphnolobium japonicum evaporates an average of 7125 liters of water, thus significantly contributing to making the urban climate more bearable. For Celtis occidentalis individuals, this value is also not negligible: 6814 liters.

\subsection{The value of trees}

The age of the trees also matters significantly, as does their current nursery average. Figure 5 shows the ratio of the average price of individuals belonging to the two species that Styphnolobium japonicum represents a higher value, despite the fact that the value of the oldest and most valuable specimens (70 years old) is around HUF 20 million. In contrast, among Celtis occidentalis, the value 
of specimens older than 90 years exceeds HUF 25 million. The slightly lower average price observed in the figure for this taxon is due to the presence of younger specimens.

The value of trees (Ft)

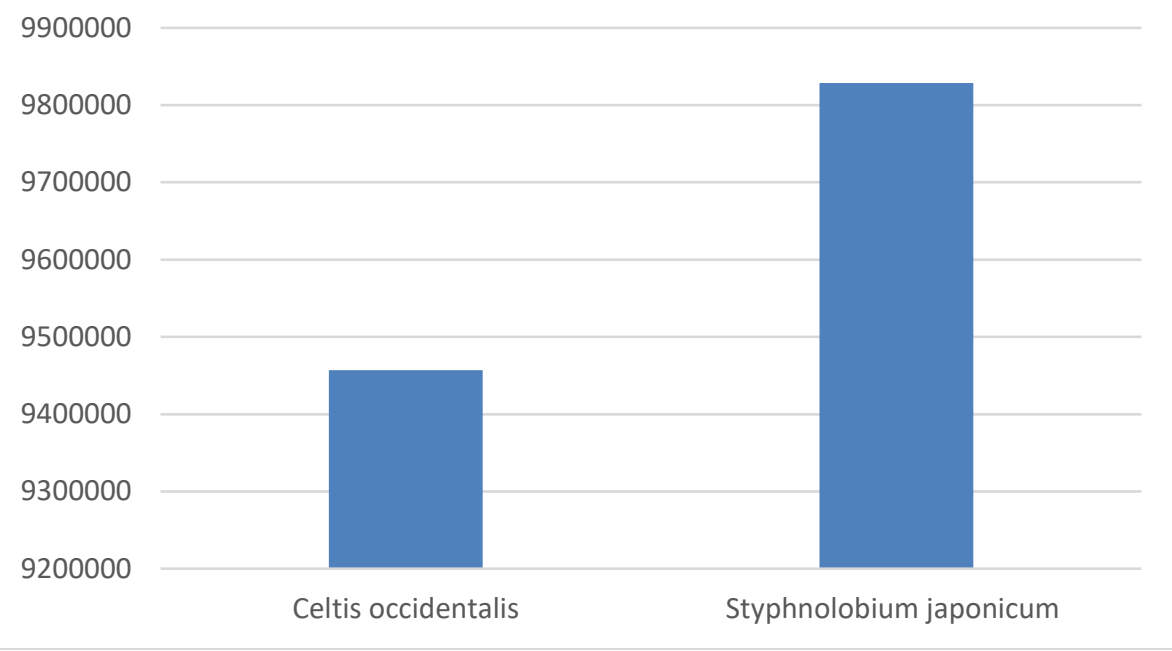

Figure 5: The value of trees

\section{Conclusions}

Of the dendrotaxons in the center of Kecskemét, two exotic species determine the green surface character of the city's main square. Thanks to the conscious planning of the ancestors, they managed to choose two trees with outstanding urban tolerance (Celtis occidentalis and Styphnolobium japonicum), which have served the population of the Great Plain county for more than half a century. Our results show that these stocks are significant and play an important role in providing a more livable environment, not only in terms of aesthetics, but also in terms of their theoretical value and ecological services. Based on the data, it is clear that the average foliage weight of common hackberry in cubic meters is higher, however, the environmental utility indicators of this group are lower in all cases. The main reason for this is that in the case of Celtis occidentalis, the standard deviation of the means is larger due to the younger individuals. In addition, in our studies, we found that their health status can also be considered good and their maximum life expectancy can be achieved with minimal maintenance, which is 130 for Celtis; and 100 years for Styphnolobium. Their importance is also supported by the fact that these two species account for $72.3 \%$ of the foliage volume of the entire woody stand.

\section{Acknowledgment}

Thank you for the support of the research carried out in the framework of the EFOP-3.6.2-162017-00012 „Developing a functional, healthy and safe food product chain model from field to table in a thematic research network". The project is funded by the Hungarian State and the European Union, co-financed by the European Social Fund, and is part of the Széchenyi 2020 program.

\section{References}

[1] Barótfi István (2000): Környezettechnika. Mezögazda Kiadó, Budapest

[2] Johnson, O. (2011): Európa fái. Kossuth Kiadó, Hongkong

[3] Jószainé Párkányi Ildikó (2007): Zöldfelület-gazdálkodás, parkfenntartás. Mezőgazda kiadó, Budapest

[4] Kim D. Coder (2018): Drought, Heat \& Trees: - a learning manual. Warnell School of Forestry \& Natural Resources, University of Georgia

[5] Radó D. (1999): Bel- és külterületi fasorok EU-módszer szerinti értékelése. A Lélegzet. 1999/7-8.

[6] Radó D. (2001): A növényzet szerepe a környezetvédelemben. Zöld Érdek Alapítvány - Levegõ Munkacsoport, Budapest. 9-20.

[7] Schmidt Gábor - Tóth Imre (2006): Kertészeti dendrológia. Mezőgazda Kiadó, Budapest 
[8] Schnier Mária (2005): A köztünk élő fák. Ismeretterjesztő kiadvány. Levegő Munkacsoport, Budapest

[9] Terpó A. szerk. (1987): Növényrendszertan az ökonómbotanika alapjaival 2, Mezőgazda Kiadó, Budapest

[10] Tóth Imre (2012): Lomblevelü díszfák, díszcserjék kézikönyve. Tarkavirág, Budapest

[11] Veperdi Gábor szerk. (2011): Erdőbecsléstan. Oktatási segédanyag. Erdővagyon-gazdálkodási és Vidékfejlesztési Intézet, Erdőrendezéstani Tanszék, Sopron 